\title{
Aldosterone Synthase Deficiency Type 1
}

National Cancer Institute

\section{Source}

National Cancer Institute. Aldosterone Synthase Deficiency Type 1. NCI Thesaurus. Code C126814.

Aldosterone synthase deficiency characterized by decreased conversion of corticosterone to 18-hydroxycorticosterone. 